\title{
Implementation of Children's Rights Execution In The Perspective of Civil And Islamic Law
}

\author{
January Nasya Ayu Taduri ${ }^{1}$, "Fairus Augustina Rachmawati ${ }^{2}$, Dian Latifani ${ }^{3}$ \\ ${ }^{1,2,3}$ Faculty of Law, Universitas Negeri Semarang \\ Email: januari.nasyaayu2000@students.unnes.ac.id \\ *fairusaugustinarachmawati@students.unnes.ac.id dan dianlatif@mail.unnes.ac.id.
}

\begin{abstract}
Divorce or the breaking up of a marriage between husband and wife through a court decision has legal consequences for both parties' rights and obligations, including children. In Indonesia, cases that are often problematic in divorce cases are the failure to achieve the execution of decisions, especially in the context of the right to support the wife and children and child custody. However, in this paper, the author is interested in examining more deeply the obstacles that occur in implementing the execution of child custody decisions that are seen from several legal perspectives, including the compilation of Islamic law, the Marriage Law, the Child Protection Law, and the regulation of the execution process of decisions. in Herziene Inlandsch Reglement (HIR). The legal research method used is Normative Law with a statutory approach or called the statute approach. This paper also uses secondary legal data sources, such as: scientific journals, books, related laws and regulations. The purpose of this paper is to provide solutions related to the obstacles that occur in the implementation of decisions on the execution of child custody rights, which until now often occur and still provide polemics both in society and within the scope of religious and state courts.
\end{abstract}

Keywords: Execution, Child Custody, Divorce.

\section{INTRODUCTION}

Basically, marriage is one form of events in the realm of civil law that regulates a man and a woman intending to live together for a long time, regulated in-laws and regulations relating to marriage (Rudianto \& Roesli, 2019). (Choirunissan, et al. 2019). Based on Article 1 The Act Number 1 of 1974 concerning Marriage, it has defined that marriage is a bond between a man and a woman to become a married couple to create a happy family and in accordance with the Almighty God (The Act Number 1 of 1974). Meanwhile, based on the Compilation of Islamic Law (KHI), it explains that marriage is a strong contract or mitssaqan ghalidzan to carry out Allah's orders and do it as worship (North Sumatra MUI 23, October 2019). In this sense, marriage can be recognized as a legal relationship between a man and a woman who meets the requirements of marriage and for the longest possible period of time (Baidhowi and Dian Latifani 2017).

Indeed, every couple wants to have a happy household, sakinah mawwadah warrahma. But in practice, no household is far from a problem. It is not uncommon for a heated argument between husband and wife to lead to divorce (Nisa Nur Amalia, et al. 2018 ). The severance of the marital 
relationship between husband and wife does not only affect their property. But it has an impact on the children born in these marriages.

As for some of the legal consequences that occur as a result of the breakdown of the engagement from marriage, as follows: 1) Child custody, 2) The right to provide a living for exwife and children, 3) Right to share assets, 4) Right to pay for education and child election. In certain cases, the parties who want to divorce have arranged all forms of legal consequences, before the divorce process in court occurs (Max Rheinstein. 1955).

However, in court practice, there are many disputes over the implementation of divorce decisions. One of the interesting clauses to be reviewed by the author in this journal is "child custody". In some cases, divorce creates disputes over childcare. The accident occurred because one of the parties did not implement the clause in the divorce decision (Retno Wulansari. 2015). Responding to disputes over child custody due to divorce, the Marriage Law does not clearly and explicitly explain child custody rights. Article 41 of the Marriage Law only explains that in the event of a dispute related to child control, the court will decide. Thus it can be understood that the Marriage Law does not specifically regulate the child's control over the mother or father (Indira Inggi A, et al. 2016). Meanwhile, Article 156 of the Compilation of Islamic Law stipulates that children who are not yet mumayyiz or have the ability to tell good and bad things or who are not yet 12 years old, the custody of their mother will fall. Then, Article 156 also regulates the person who has the right to replace his mother's position if he dies.

If the facts in court reveal that the mother is a drunkard, the verdict on child care in a divorce case at the Religious Court can be carried out if one of the parties voluntarily wants to implement the decision's contents. In practice, if one party is not willing to implement a decision voluntarily, the decision execution procedure must be carried out. In theory, decisions on child care in divorce cases can be executed. It's just that casuistically it needs to be taken through a psychological and conditional aspect approach as well as being juridically consistent (Wildan Suyuthi Mustofa. 2002).

Execution of child-rearing in divorce cases is included in executions, which contain very complex problems. This is because, from a procedural point of view, procedures are not specifically regulated in statutory regulations. On the other hand, the object of this execution is a living creature, so that in its implementation, it cannot be enforced by force like an inanimate object. Problems in the execution process have the potential to cause obstacles in the execution process. The constraints in question can occur due to several factors, as follow aslaw: a juridical perspective, legal provisions, and from a non-juridical perspective. 
So that in this paper, we will discuss the problems in the execution of child custody decisions based on legal arrangements such as the Compilation of Islamic Law, Marriage Arrangements, HIR, the Child Protection Law, and the Child Convention, to provide solutions related to solving problems in the execution of custody. Child. The main problems used in this paper are as follows:

a) What are the problems that occur in the execution of child custody cases?

b) How the efforts and legal certainty for the completion of the execution of child custody cases?

\section{RESEARCH METHODS}

In this paper, the writer uses doctrinal law research or normative law research, wherein this research, it examines the aspects of the problems that exist in a positive law (Kornelius Benuf \& Muhammad Azhar. 2020). This research method is also often interpreted as a research technique on statutory regulations viewed from the standpoint of a vertical law and horizontal harmonization of legislation. This paper's research is rational theoretical, and the logic form of the reasoning is deductive logic (Depri Liber Sonata. 2014). The author in this research used a qualitative research approach. It is like a Ladescriptive and analytical research. This qualitative research also aims to understand a phenomenon described in the form of a word or sentence in a context that utilizes various approaches contained therein.

More specifically, this paper uses a statutory legal approach or often referred to as a statute approach. In this case, Prof. Peter Mahmud explained through his book entitled Legal Research states that a statutory approach is an approach that uses legislation or regulation. Besides, this research approach also understands hierarchy and principles in statutory regulations (Peter Mahmud Marzuki. 2005).

This research aims to analyze the various obstacles in implementing divorce decisions related to child custody based on related regulations to provide input regarding problems in the execution of child custody. In this paper, the author uses secondary legal data sources consisting of books, scientific journals, official documents, reports, and statutory regulations (Soerjono Soekanto. 2015). The regulations used in this journal article include Marriage Law, Islamic Law Compilation, Herziene Inlandsch Reglement (HIR), Rechtsreglement voor de Buitengewesten $(R B g)$, Child Protection Law, and Conventions related to Children's Rights.

\section{RESULTS AND DISCUSSION}

\section{A. Arrangements and Mechanisms for Execution of Child Custody Decisions}


Literally, execution comes from the word "executie" which means uitvoer leggig van vonnissen or executing the judge's decision. Whereas the Execution of Civil Decisions is the implementation of decisions in the civil domain by force based on the prevailing laws and regulations due to the parties' unwillingness to be executed voluntarily to carry out the results of court decisions (Dian Latifiani. 2015). In this case, Yahya Harahap in his book entitled "The Scope of Problems in Civil Execution" states that executions can be carried out in judges' decisions that have permanent legal force against the losing parties in the trial (M. Yahya Harahap, 1988). A decision having legal force can still be submitted for the winning party's execution if the losing party makes the decision voluntarily. The execution is carried out by order of the court's head through the bailiff or the clerk.

The verdict that can be submitted for execution is the verdict with Amar condemnatoir punishing, while the declatoir or constitutive decision cannot be carried out. Decisions can be classified as BHT, if: a) First level decisions that are not filed for appeal/cassation, b) Decisions on appeal that are not filed for cassation, c) Cassation decisions from the Constitutional Court, d) Verzet decisions of the first level that are not challenged, e) Decisions with peaceful results between parties. All warnings from a legally binding decision must be carried out thoroughly. There are several types of executions: 1) Execution punishes the losing party to pay a certain amount of money, 2) Execution of a decision punishes a legal subject to fulfill an act, and 3) Real execution or a judge's decision to vacate a place. In the context of the execution of a custody decision, the execution is in the form of fulfilling the act by a legal subject. The procedures for the execution of decisions are regulated in Herziene Inlandsch Reglement (HIR) Articles 195-224 with the following main stages: a) Warning, b) Issuance of execution order, c) Making an execution report (Subekti. 1989).

Child custody rights are regulated in several scopes of different laws and regulations. Based on The Act Number 1 of 1974 concerning Marriage, Article 45 paragraph 1 stipulates that parents have an obligation to care for and educate their children properly (Umar Haris Sanjaya, 2015). Then Article 47 explains that it is the obligation of parents to look after children who are under 18 years of age and above or to marry. This will continue as long as the court does not revoke the parental rights. The Marriage Law does not specifically regulate definitions, benchmarks or requirements related to child custody after divorce.

Whereas in the Islamic Law Compilation (hereinafter referred to as KHI) explaining the custody of children after the break-up of marriage through death or divorce is referred to as Hadhanah, which is the obligation of parents to care for children with the following objectives: a) Ensuring the availability of clothing, food and shelter for their children, b) Educate their children 
for a good life in this world and the hereafter, c) Protect children from bad things and harm them (Farida Prihatini, et al. 2019). Based on Presidential Instruction Number 1 of 1991 concerning the Dissemination of the Compilation of Islamic Law in Articles 98 to 106 explains that the age limit for childcare is until the child can take care of his own life or is 21 years old or has been married, parents have the right to represent the child against all legal actions in court as well as outside courts and religious courts can appoint a candidate for guardian for their child if the parents are unable to carry out their duties. Then in Article 105 that the maintenance of children resulting from divorce if they are under 12 years of age or not yet normal, but when the children are mummayiz the children can choose who they will stay with and the father bears the maintenance costs (Nisa 'Nur Amalia. Op. cit. Pp. 37-38).

The KHI also regulates the requirements for child custody (Hadhanah), as follows: a) adult, b) sensible, physically and mentally healthy, c) has the ability to care for children, d) trustworthiness and morals, e) is Muslim, f) if the biological mother has the right to care for a child, g) A non-Muslim has no rights and is not allowed to be a carer for a child.

In determining the imposition of child custody, the judge can pay attention to several other regulations, such as The Act Number 35 of 2014 concerning Amendments to The Act Number 23 of 2002 concerning Child Protection regulates that a child is someone who is not or under the age of 18 and the power of custody is the power of parents to provide care, education, fostering, nurturing, protection and developing children according to their religion or belief according to their talents and interests (The Republic of Indonesia. The Act Number 35 of 2014) Based on Article 14 paragraphs (1) and (2) it also states that every child has the right to receive care from his parents but if reasons or legal rules are governing the separation of children and parents is the best way or decision for the child, then it is allowed. This Article also states that if a child is separated, there are children's rights that need to be fulfilled, such as: the child still has the right to meet and relate to his parents, to receive care, education, protection, maintenance, living expenses and other rights as children by his parent (Ibid, Article 14 paragraph (1) and (2).

In line with the Child Protection Law, the Child Convention adheres to 4 main principles, as follow as: 1) Non-discrimination, 2) The best interests of the child, 3) The right to live and develop, 4) Giving respect to children (Nisa Nur Amalia, Op Cit p. 39). Responding to laws and regulations regarding child protection and child conventions, it can be understood that child custody also emphasizes children's interests. In addition, it can also be interpreted that the regulation of child custody is spread out in several domains of legislation such as Marriage Law, Islamic Law Compilation, Child Protection Law and Child Convention. In other words, in deciding 
the child custody clause, the judge can pay attention and consider some of the juridical aspects above and non-juridical aspects, such as psychological, affection or other related aspects.

\section{B. Barriers to Execution of Child Custody}

The several obstacles that hinder the execution of child custody decisions are divided into two, as follow as:

1. Obstacles to the execution of juridical child custody

In carrying out the execution of child care in divorce cases, this creates obstacles in the juridical execution process, several problems that occur in the execution of child custody, such as:

a. The regulations regarding the execution of child custody have not been enforced

The obstacle that occurs is that the execution of child custody decisions is not because there is no legal rule, but there are no compiled legal rules governing child care execution. Also, the regulation regarding the implementation of execution in positive law in Indonesia has not been regulated, wherein the execution of child custody in divorce cases that occurs in Indonesia has not yet regulated detailed regulations regarding this execution which causes the execution process to be hampered. So that if this execution actually appears in the community, the execution device will experience uncertainty in determining which rules will be used

In this paper, the author considers that legal certainty is one of the most important components in carrying out the judicial process. As it is known, Indonesia is a country based on law or "rechtsstaat" and not based on power or "machtsstaat" (Nunung Nugroho. 2017).Thus, all public and government actions in carrying out the state's life cannot be separated from the rule of law. In line with this, Gustav Radbruch classifies the law into three identities: 1) The principle of legal certainty or rechmatigheid, 2) The principle of legal justice or gerectigheit, 3) The principle of legal benefit or zwechmatigheid / doelmatigheid 'Sidik Sunaryo and Shinta Ayu Purnamawati. 2019). Legal certainty is interpreted as a principle that has the highest position in administering the rule of law. Also, Jan Michiel Otto emphasized that legal certainty can occur if there are clear, consistent, and easily obtaine (Muammar Alay Idrus. 2017).

Considering some of these jurists' serious opinions, the writer feels that uncompiled legal rules can cause legal ambiguity so that the law is uncertain. In other words, the lack of clarity in legal rules related to child custody can create doubts in issuing court decisions and trigger obstacles in the execution of these decisions.

2. Barriers to implementing non-juridical child custody rights 
In carrying out the execution of child care in divorce cases, it creates obstacles in the nonjuridical execution process, while the obstacles that occur in the execution of non-juridical child custody rights are as follows:

a. The execution apparatus is not prepared at the Religious Courts.

After the enacted the Act Number 7 of 1989, the judicial function's actual implementation is the appointment of a Seizure Jury and a Substitute Bailiff. However, in terms of quality, it is still untested. This is because most of the Bailiffs and Substitute Bailiffs still do not understand the procedures for marital confiscation, bail, and execution seizures in the field. In fact, this Bailiff and Substitute Bailiff will carry out the complete execution function, starting from the parties' summoning to the implementation in the field. In terms of quantity bailiffs and substitute confiscators at each religious court.

b. The defendant's resistance to execution in a child custody case

Executing means forcing the executed party to vacate or hand over the object of the dispute to the party requesting execution so that if the executed person remains on the object of the dispute in the sense that he does not want to hand over to the applicant for execution, it can result in postponing the execution (Teguh Suriyanto. 2015). In The Act Number 1 of 1974, article 41, both parents are obliged to care for and educate their children, including providing the necessary fees. But in the execution process, the party often responds to the execution and does not want to carry out the execution order's execution. Therefore, various attempts were made by the party to be executed, including hiding the child who was the object of execution to filing a legal action (Umul Khair. 2020). The legal action taken is extraordinary legal action (Reconsideration) against the verdict to be executed. The extraordinary legal action taken by the defendant in the execution, in theory, cannot stop the execution. In several cases, both the defendant and the court were waiting for the Supreme Court's decision. This results in the execution process being delayed.

c. The object of execution is human.

Children are social beings who have dignity and dignity. Children also have desires that they want to follow (Nelly Layaliyal Fitri. 2019). According to the Convention on the Rights of the Child (CRC), Article 3 states that in all actions concerning children, whether carried out by public or private social welfare institutions, courts, administrative authorities or legislative bodies, the child's best interests must come first (Jay G. Silverman, etc. 2004). Article 14 of The Act Number 23 of 2002 Concerning Child Protection, which reads "Every child has the right to be cared for by his own 
parents, unless a valid reason or legal rule is indicating that separation is in the best interest of the child and is the final consideration for Divorce (Zulfan Efendi. 2020). In the execution object, which is a child, it is unique. This is because in the provisions in the execution of civil cases at the District and Religious Courts, the object of execution is inanimate objects. The object of execution, which is not an inanimate object, certainly creates problems in its implementation. Execution of inanimate objects could have been carried out on the party the defendant was executed, but against children, it is not as easy as for inanimate objects. In its implementation, it is necessary to pay attention to the child's psychological factors, so that it does not cause trauma to the child in the future.

The examples of cases related to the struggle for child custody are as follows:

Andre Setyawan and Nova Aryani have married on January 14, 2002, and have been blessed with 3 children. In the beginning, her household was fine, until 2008-2009. There were disputes and fights caused by Nova Aryani's attitude of not carrying out her obligations as a wife and mother of 3 children. Even after coming home from work, Andre Setyawan had to cook and prepare food for his children. When Andre Setyawan could not fulfill his wish, Nova Aryani easily said the word Cerai. Currently, the three children live with Nova Aryani at their parents' house. All the needs of these children, from school pick-up, education and private lessons, all who pay attention are Andre Setyawan and his parents.

Daily necessities Mrs. Andre Setyawan sent groceries to Nova Aryani's parent's house. In October 2015, Nova Aryani expelled Andre Setyawan. During their separation, the three children lived with Nova Aryani and their parents, but Nova Aryani never cared about her three children, she often went out with her friends and often went out at night with the boys. In fact, Ibu Nova Aryani does the cooking for her children. Sometimes, the private tutors from her children also help feed the children. In the Judge's Decision Number 3346 / Pdt.G / 2016 / PA.Sby has decided that child custody (Hadhanah) falls to the father. This decision explains that custody of children can also fall to the father as long as the father can fulfill all the requirements as the holder of custody.

\section{Solution Efforts in the Implementation of Child Custody Rights}

Based on the obstacles described above in implementing child custody rights in divorce cases, all efforts or solutions are needed to overcome these obstacles, including:

1. A third person (mediator) is needed in the process of implementing child custody rights.

Because the case that occurs in the execution of child custody of the object being executed is a human, a third party's assistance can be used as a mediator in its settlement and implementation. The head of the court and the execution apparatus must know the actual facts/conditions regarding the case for which execution is requested. This is the basis 
for determining execution steps, so that this execution can be carried out under applicable regulations.

2. Improvements in training and coaching specifically for execution devices

In Government Regulation No. 9 of 1975 Article 24 paragraph (2), During the ongoing divorce lawsuit at the plaintiff or defendant's request, the Court may determine matters necessary to ensure children's care and education (Anjar SC Nugraheni, et al. 2013). To be able to execute child custody, special training is needed to provide provision and guidance to the execution equipment at the Religious Courts, so that the Bailiff and Substitute Bailiff can carry out their functions properly in each court.

3. Legal discovery efforts made by the judge

In making an effort to find a solution because there are no regulations regarding the implementation of child custody rights, the only way to be used is through legal discovery. legal discovery is the process of forming by judges, or other legal officers who are assigned to the application of general law regulations in concrete legal events (Achmad Arief Budiman. 2014).

Besides, the author also adds that legal uncertainty can be dealt with by conducting national unification or unification of laws (Anak Agung Putu Wiwik Sugiantari. (2015)., because the regulation of child custody is divided into 3 domains of legislation, such as: Marriage Law, compilation of Islamic law and child protection law. According to the author, this creates legal confusion, leading to legal uncertainty, because the law is not interpreted clearly. In this case, the authors consider that "if there is no unification or unification of the law, it will worsen the existing conditions".

In addition, issues related to child custody in public and private courts are in second place after problems with sustaining wives and children.

On the other hand, the KPAI (Indonesian Child Protection Commission) stated that in 2018 there were 4,885 complaints of cases of violations of children's rights. Cases of child violations are considered to fluctuate every year. However, the head of KPAI (Susanto) emphasized that violations of children's rights due to family and alternative care were in second place with 857 (Kompas. (January, 1 2019). So, it is necessary to have clearer and more comprehensive laws and regulations related to child custody to minimize violations of children's rights due to divorce. 


\section{CONCLUSION}

It can be concluded that divorce has legal consequences for all aspects of the family. Not only limited to property, but also children. In some cases, divorce has problems, especially those related to child custody, one of which is the failure of the decision to execute child custody. The custody of children is regulated in several laws and regulations, such as: the Marriage Law, the Compilation of Islamic Law and the Law on Child Protection. The execution of child custody has not always gone smoothly. As for several obstacles and efforts in implementing child custody rights, it can be concluded that the obstacles to implementing child custody in Indonesia are divided into 2 (two). There are juridical and non-juridical.

The juridical obstacles are the absence of regulations regarding the execution of child custody and the unpreparedness of the Religious Courts' execution apparatus. Then the problem of a non-juridical nature is the defendant's resistance to the execution in a child custody case and the object of execution is a human. So that efforts that can be made in overcoming problems in implementing child custody can be in the form of the need for a third person (mediator) in the process of implementing child custody rights, improvement in training and special guidance for execution instruments, as well as legal discovery efforts by judges.

\section{REFERENCES}

A, Indira Inggi, et al. (2016). Kajian Perolehan Hak Asuh Anak Sebagai Akibat Putusnya Perkawinan Karena Perceraian. Diponegoro Law Review. 5(2).

Amalia, Nisa Nur, et al. (2018). ANALISIS YURIDIS PUTUSAN HAKIM No. 3346/Pdt.G/2016/PA.Sby TENTANG AYAH SEBAGAI PEMEGANG HAK ASUH ANAK. Jurnal Res Judicata. 1(1).

Baidhowi and Dian Latifani. (2017). ISTBAT OF MARRIAGE IMPLEMENTATION FOR MARRIAGE AFTER ENACTMENT OF LAW NO. 1 OF 19741. Journal of Islamic Law Studies, Sharia Journal, 2 (1).

Benuf, Kornelius \& Muhammad Azhar. (2020). Metodologi Penelitian Hukum sebagai Instrumen Mengura Permasalahan Hukum Kontemporer. Jurnal Gema Keadilan. Volume 7.

Budiman, Arief Achmad. (2014). Penemuan Hukum dalam Putusan Mahkamah Agung dan Relevansinya bagi Pengembangan Hukum Islam Indonesia. Jurnal Pemikiran Hukum Islam 24(1).

Choirunissan, et al. (2019). Analisis Hukum Islam terhadap Faktor Putusnya Tali Perkawinan. Samarah: Jurnal Hukum Keluarga dan Hukum Islam 3 (2). 
Efendi, Zulfan. (2020). Pelaksanaan Eksekusi Hak Asuh Anak (Hadhanah) Terhadap Isteri yang Murtad dalam Perkara Nomor: 398/P.dt.G/2013/PA.Pbr di Pengadilan Agama Pekanbaru). Jurnal Syariah dan Hukum 02(01).

Fitri, Nelly Layaliyal. (2019). Eksekusi Hak Asuh Anak di Dua WilayahYuridiksi Prespektif Undang-Undang Perlindungan Anak No 35 tahun 2014 (Studi Putusan Nomor 1813/Pdt.G/PA.Kab.Kediri). Journal of Family Studies, 3(1).

Harahap, M. Yahya. (1988). Ruang Lingkup Permasalahan Eksekusi Bidang Perdata. Jakarta : Sinar Grafika.

Idrus, Muammar Alay . (2017). Keabsahan, Kepastian Hukum dan Perlindungan Hukum Atas Perwakafan Yang Tidak Tercatat (Studi Kasus Praktek Perwakafan Tanah di Kecamatan Sukamulia). Jurnal IUS Kajian Hukum dan Keadilan, 5(1).

Khair, Umul. (2020). Pelaksanaan Hak Asuh Anak Setelah Terjadinya Perceraian. Jurnal Cendekia Hukum Vol 5(2).

Kompas. ( Januari, 1 2019). Sepanjang 2018, KPAI Terima 4.885 Kasus Pelanggaran Hak Anak. Kompas.com. Dikutip dari https://nasional.kompas.com/read/2019/01/08/18472551/sepanjang-2018-kpai-terima4885-kasus-pelanggaran-hak-anak . Accessed on November 232020.

Latifiani, Dian. (2015). Permasalahan Putusan Hakim. Jurnal Hukum Acara Perdata. 1(1).

Marzuki, Peter Mahmud . (2005). Penelitian Hukum Edisi Revisi. Jakarta : Kencana Predana Media Group.

MUI SUMUT. (23, Oktober 2019). Perkawinan Dalam UU No 1 Tahun 1974 dan Kompilasi Hukum Islam. Majelis Ulama Indonesia Sumatra Utara. Dikutip dari https://www.muisumut.com/blog/2019/10/23/perkawinan-dalam-uu-no-1-tahun-1974dan-kompilasi-hukum-islam/ . Accessed on November 222020.

Nugraheni, Anjar S C et.al. (2013). Komparasi Hak Asuh dan Hak Nafkah Anak Dalam PutusanPutusan Perceraian di Pengadilan Negeri dan Pengadilan Agama Kota Surakarta. Yustisia 2(3).

Nugroho, Nunung . (2017). Urgensi Pembaruan Kitab Undang-Undang Hukum Pidana Dalam Dinamika Masyarakat Indonesia. Jurnal Spektrum Hukum, 14(1).

Prihatini, Farida. et.al. (2019). The Problem of The Execution of Child Custody (Hadanah) Decision by The Religious Courts in Indonesia. Journal Syariah, 27(2).

Republik Indonesia. Undang-Undang Nomor 1 Tahun 1974 tentang Perkawinan.

Republik Indonesia. Undang-Undang Nomor 35 Tahun 2014 Tentang Perubahan Atas UndangUndang Nomor 23 Tahun 2002 Tentang Perlindungan Anak

Rudianto, E., \& Roesli, M. (2019). Civil Law Review Non-performing Loan Settlement Loans Revolving Funds National Program for Community Empowerment in Urban. YURISDIKSI: 
Jurnal Wacana Hukum Dan Sains, 14(1), 58-73.

Rheinstein, Max .(1955). The Law of Divorce and the Problem of Marriage Stability. VANDERBILT LAW REVIEW, 9.

Sanjaya, Umar Haris. (2015). Keadilan Hukum Dalam Pertimbangan Hakim Dalam Memutus Hak Asuh Anak. Jurnal Yuridika, 30(2).

Silverman, Jay G., et.al. (2004). Child Custody Determinations in Cases Involving Intimate Partner Violence: a Human Rights Analysis. Am J Public Health, 94(6).

Sonata, Depri Liber. (2014). Metode Penelitian Hukum Normatif dan Empiris: Karakterisrik Khas Dari Metode Penelitian Hukum. Fiat Justicia Jurnal Ilmu Hukum, 8(1).

Soekanto, Soerjono. (2015). Pengantar Penelitian Hukum. Jakarta : UI Press.

Subekti. (1989). Hukum Acara Perdata. Bandung : Binacipta.

Sugiantari,Anak Agung Putu Wiwik. (2015). Perkembangan Hukum Indonesia Dalam Menciptakan Unifikasi dan Kodifikasi Hukum. Jurnal Advokasi 5(2).

Suriyanto, Teguh . 2015. Tinjauan Hukum Tentang Kendala-Kendala Eksekusi Yang Telah Inkracht (Studi Pada Pengadilan Negeri Palu). Jurnal Ilmu Hukum Legal Opinion 3(3).

Sunaryo, Sidik dan Shinta Ayu Purnamawati. (2019). Paradigma Hukum Yang Benar dan Hukum Yang Baik (Perspektif Desain Putusan Hakim Perkara Korupsi di Indonesia). Trijurnal Lemilit Trisakti. 1(2).

Wulansari, Retno. (2015). Hambatan dalam Proses Eksekusi Putusan terhadap Pemeliharaan Anak dalam Perkara Perceraian di Pengadilan Agama. Jurnal Supremasi Hukum. 4(2).

Wildan Suyuthi Mustofa. (2002). Pemecahan Permasalahan Acara Perdata Peradilan Agama, Ctk. Pertama, PT Tatanusa, Jakarta. 